\title{
Changes in the Transcriptome Profiles of Human Amnion-Derived Mesenchymal Stromal/Stem Cells Induced by Three-Dimensional Culture: A Potential Priming Strategy to Improve Their Properties
}

\author{
Alessia Gallo ${ }^{1,+}{ }^{+}$Nicola Cuscino ${ }^{1,+}{ }^{\mathbb{D}}$, Flavia Contino ${ }^{1}$, Matteo Bulati ${ }^{1}$ D , Mariangela Pampalone ${ }^{2,3}$ (D), \\ Giandomenico Amico 2,3 ${ }^{\text {D }}$, Giovanni Zito ${ }^{1}$ (D), Claudia Carcione ${ }^{2}$, Claudio Centi ${ }^{1}$, Alessandro Bertani ${ }^{4}$, \\ Pier Giulio Conaldi ${ }^{1}$ (D) and Vitale Miceli ${ }^{1, * \mathbb{D}}$
}

check for updates

Citation: Gallo, A.; Cuscino, N.; Contino, F.; Bulati, M.; Pampalone, M.; Amico, G.; Zito, G.; Carcione, C.; Centi, C.; Bertani, A.; et al. Changes in the Transcriptome Profiles of Human Amnion-Derived Mesenchymal Stromal/Stem Cells Induced by Three-Dimensional Culture: A Potential Priming Strategy to Improve Their Properties. Int. J. Mol. Sci. 2022, 23, 863. https:// doi.org/10.3390/ijms23020863

Academic Editors: Tullia Maraldi and Valentina Russo

Received: 21 December 2021

Accepted: 11 January 2022

Published: 13 January 2022

Publisher's Note: MDPI stays neutral with regard to jurisdictional claims in published maps and institutional affiliations.

Copyright: (C) 2022 by the authors. Licensee MDPI, Basel, Switzerland. This article is an open access article distributed under the terms and conditions of the Creative Commons Attribution (CC BY) license (https:// creativecommons.org/licenses/by/ $4.0 /)$.
1 Research Department, IRCCS ISMETT (Istituto Mediterraneo per i Trapianti e Terapie ad Alta Specializzazione), 90127 Palermo, Italy; agallo@ismett.edu (A.G.); ncuscino@ismett.edu (N.C.); fcontino@ismett.edu (F.C.); mbulati@ismett.edu (M.B.); gzito@ismett.edu (G.Z.); ccenti@ismett.edu (C.C.); pgconaldi@ismett.edu (P.G.C.)

2 Fondazione Ri.MED, 90127 Palermo, Italy; mpampalone@fondazionerimed.com (M.P.); gamico@fondazionerimed.com (G.A.); ccarcione@fondazionerimed.com (C.C.)

3 Department of Laboratory Medicine and Advanced Biotechnologies, IRCCS ISMETT (Istituto Mediterraneo per i Trapianti e Terapie ad Alta Specializzazione), 90127 Palermo, Italy

4 Thoracic Surgery and Lung Transplantation Unit, IRCCS ISMETT (Istituto Mediterraneo per i Trapianti e Terapie ad Alta Specializzazione), 90127 Palermo, Italy; abertani@ismett.edu

* Correspondence: vmiceli@ismett.edu; Tel.: +39-09-1219-2430

+ These authors contributed equally to this work.

Abstract: Mesenchymal stromal/stem cells (MSCs) are believed to function in vivo as a homeostatic tool that shows therapeutic properties for tissue repair/regeneration. Conventionally, these cells are expanded in two-dimensional (2D) cultures, and, in that case, MSCs undergo genotypic/phenotypic changes resulting in a loss of their therapeutic capabilities. Moreover, several clinical trials using MSCs have shown controversial results with moderate/insufficient therapeutic responses. Different priming methods were tested to improve MSC effects, and three-dimensional (3D) culturing techniques were also examined. MSC spheroids display increased therapeutic properties, and, in this context, it is crucial to understand molecular changes underlying spheroid generation. To address these limitations, we performed RNA-seq on human amnion-derived MSCs (hAMSCs) cultured in both 2D and 3D conditions and examined the transcriptome changes associated with hAMSC spheroid formation. We found a large number of 3D culture-sensitive genes and identified selected genes related to 3D hAMSC therapeutic effects. In particular, we observed that these genes can regulate proliferation/differentiation, as well as immunomodulatory and angiogenic processes. We validated RNA-seq results by qRT-PCR and methylome analysis and investigation of secreted factors. Overall, our results showed that hAMSC spheroid culture represents a promising approach to cell-based therapy that could significantly impact hAMSC application in the field of regenerative medicine.

Keywords: human amnion-derived mesenchymal stromal/stem cells; RNA sequencing; 3D priming; MSC spheroids; MSC therapeutic properties; regenerative medicine

\section{Introduction}

In the last decade, many studies have highlighted the potential use of mesenchymal stromal/stem cells (MSCs) as a therapeutic tool to be applied in the field of regenerative medicine [1-5]. MSCs exhibit immunomodulatory, angiogenic, and regenerative capabilities, and these properties are mediated, at least in part, by paracrine mechanisms due to secretion of soluble factors [6-14]. Moreover, MSC abilities have raised them as a therapeutic tool in several clinical trials for the treatment of many disorders. However, the 
results obtained from these studies are controversial [15-18]. This phenomenon is probably related to the intrinsic properties of MSCs, which are derived from different sources $[9,19]$. Therefore, there is a need for improvement of MSC culture/production to enhance their therapeutic properties $[3,20,21]$.

MSCs are found in several tissues, including bone marrow [22], adipose tissue [23], umbilical cord [24], and placenta [25], where these cells exhibit immunomodulatory [6,26-28], angiogenic [27,29,30], and antioxidative properties [31]. Regarding the source of MSCs, because of ethical issues and invasiveness for cell procurement, in recent years, increasing evidence supports the use of perinatal tissues, such as umbilical cord and placenta (e.g., amniotic membrane), as a useful source of MSCs [27,32,33]. Perinatal tissue shows several advantages, including the number of cells that can be easily obtained without any invasiveness.

It has been shown that MSC paracrine properties can be modulated by some preconditioning methods, including the growing of MSCs under three-dimensional (3D) culture conditions. Indeed, in response to 3D MSC priming/activation, the production of factors is switched toward a more anti-inflammatory and pro-trophic phenotype that results in an improvement in MSC therapeutic properties [21,34-36]. Our previous studies have shown that preconditioning of MSCs by 3D cultures enhances the secretion of functional factors. In particular, we revealed that conditioned medium (CM) derived from MSC spheroids was enriched with bioactive factors able to: (1) improve both wound healing and immunoregulatory capacity [27,37]; (2) enhance liver progenitor differentiation in an in vitro model of human liver organoids [8]; (3) attenuate the effects of cold ischemia-reperfusion injury in human alveolar epithelial cells [10]. Moreover, it has been demonstrated that when MSCs are grown as spheroids, they acquire stemness properties, increase cell survival, and improve their differentiation potential [34]. Therefore, spheroid formation can be considered as an optimization of MSC culture to enhance their therapeutic potential [20,21,38,39].

Recently, specific "omics" techniques were utilized to describe different biological processes. In particular, transcriptome analysis was used to understand MSC biological changes related to specific priming treatments (e.g., IL-17, IFN- $\gamma$, and hypoxia) $[40,41]$ or to compare cells derived from different sources [42,43]. In recent years, total RNA sequencing (RNA-seq) using next-generation sequencing (NGS) platforms has greatly improved the analysis of whole transcriptomes, allowing for the individuation and quantification of the expression of a large number of genes. This technology can provide an unbiased analysis of the MSC activity with crucial insights into the affected cellular pathways. Thus, genomewide molecular characterization of MSCs can allow the identification of their properties. This is very crucial to understand the appropriate culture methods to make MSCs suitable in the field of regenerative medicine.

In this work, we used RNA-seq analysis to provide a holistic view of transcriptome changes after 3D culture generation of human amnion-derived MSCs (hAMSCs). We observed extensive changes in gene expression profile (>9000 genes) following 3D cultures. Among 9000 deregulated genes, >4000 genes were upregulated, and Kyoto Encyclopedia of Genes and Genomes (KEGG) pathway analysis and Gene Ontology (GO) pathways analysis revealed that 30 upregulated genes were potentially implicated in crucial pathways involved in the regenerative processes. These findings highlight the importance of optimizing culture methods to maximize the therapeutic potential of MSCs. Understanding cellular responses following appropriate culture methods will help evaluate MSC application for specific biomedical applications.

\section{Results}

\subsection{Isolation, Characterization, and Culture of hAMSCs}

Primary cultures of MSCs were derived from the human amniotic membrane of the placenta, and adherent cells were expanded in vitro until Passage 2. Then, hAMSCs were grown in parallel in two-dimensional (2D) cultures (displaying morphologic and molecular characteristics that define MSCs) (Figure 1a-c) and in a suspended state (3D cultures), where cells spontaneously aggregated and formed compact multicellular spheroids (Figure 1a, 
right). Flow cytometry data showed positive expression of CD90 (98.50\%), CD73 (96.60\%), and CD13 (83.80\%) and negative expression of hematopoietic lineage markers CD45 (0.73\%) and HLA-DR $(0.30 \%)$ (Figure $1 \mathrm{~b}, \mathrm{c})$.

2D Cultures
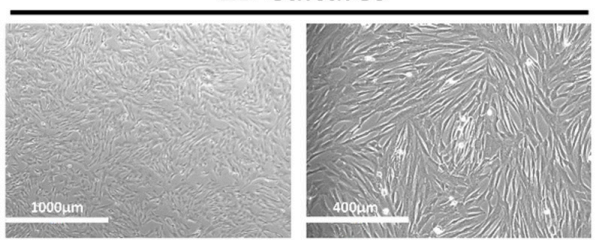

3D Cultures

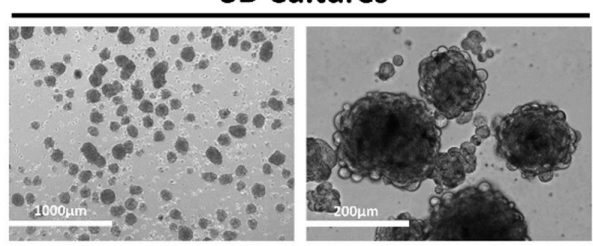

(a)

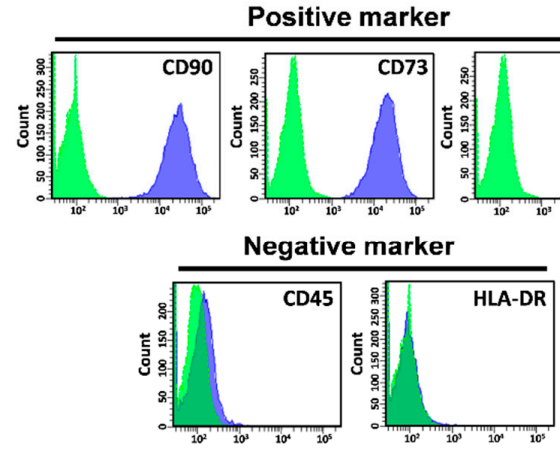

(b)

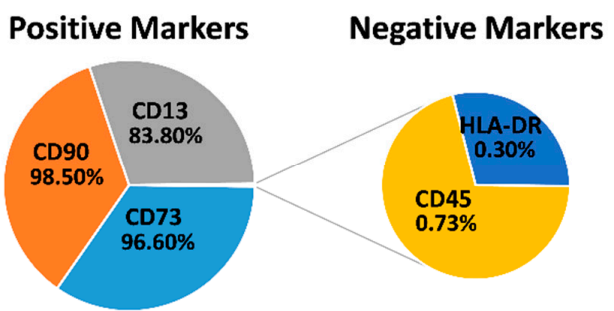

(c)

Figure 1. Human amnion mesenchymal stem cells (hAMSCs) grown as both monolayer and spheroids. (a) Representative DIC images of hAMSCs grown in monolayer (2D cultures) or as spheroids (3D cultures). (b) Representative images of flow cytometry analysis for quantification of both positive and negative surface markers in hAMSCs at Passage 0. Green represents isotype control, and blue represents stained cells. (c) Graphic depicts the percentage of each marker. DIC, differential interference contrast.

2.2. Gene Expression Profiles in $2 D$ and $3 D$ hAMSCs Revealed Enhanced Regenerative Properties of the hAMSC Spheroids

We used RNA-seq to examine gene expression changes in both 2D and 3D hAMSC cultures. We applied transcripts per kilobase million (TPM) to normalize and quantify each gene expression. About 19,000 genes were identified in both cultures (Figure 2a). In each sample, a relatively high expression (TPM $\geq 50$ ) of $18.9 \%$ (2D hAMSCs) and 19.5\% (3D hAMSCs) was detected (Figure 2a). Among these genes, the volcano plot $(p<0.05$ and FC > 1.5) revealed 9221 significant differentially expressed genes (DEGs) (Figure 2b), where 3899 were downregulated, and 5322 were upregulated in 3D hAMSCs compared to 2D hAMSCs (Figure 2c). Interestingly, principal component analysis (PCA) and the heat map of DEGs clustered the samples into two distinct groups based on 2D or 3D cultures (Figure 2c,d).

Both KEGG and GO enrichment analysis revealed that, among the top 3000 upregulated genes found in 3D hAMSCs, many DEGs were linked to immunomodulation, proliferation/differentiation, and angiogenesis. For example, KEGG analysis showed that the only two significant enriched pathways were the "TNF signaling pathway" and the "NF-kappa B signaling pathway" (Figure 3a). Many of the GO terms (ranked by p-value) associated with DEGs for 3D hAMSCs were also related to aspects of immune regulation, cellular growth, differentiation, and angiogenesis, including the terms "regulation of neuroinflammatory response", "inflammatory response", "positive regulation of glial cell differentiation", "positive regulation of p38MAPK cascade", "cytokine activity", and "growth factor activity" (Figure 3b,c) 


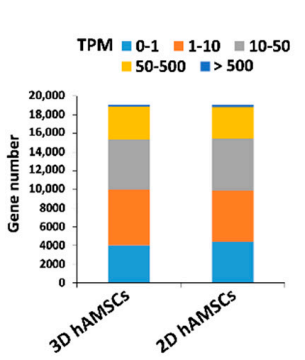

(a)

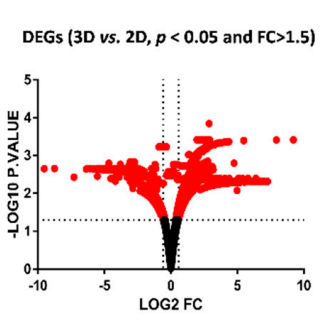

(b)

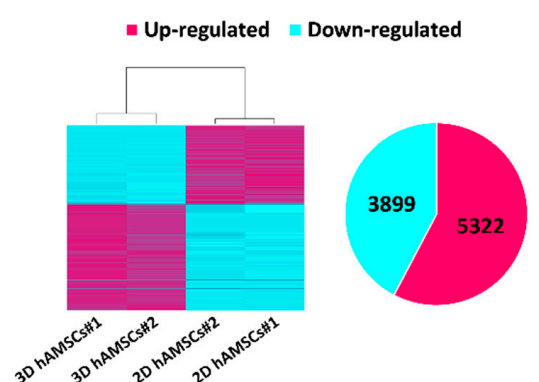

(c)

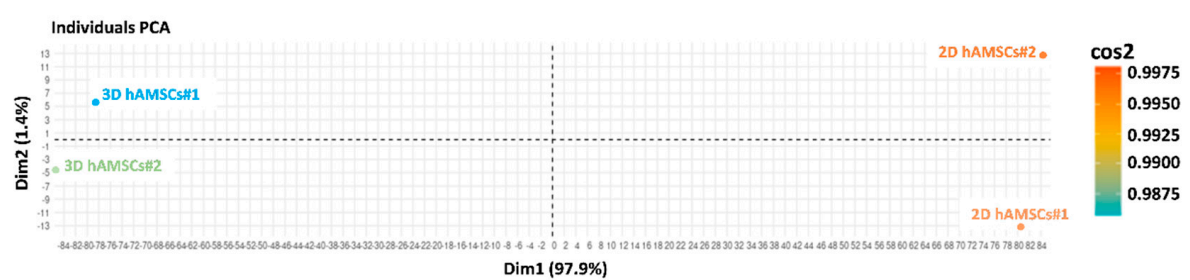

(d)

Figure 2. Gene expression profiles and differential expression in human amnion mesenchymal stem cells (hAMSCs) grown as both monolayer (2D) and spheroids (3D). (a) Gene expression distribution in both 2D and 3D hAMSCs. (b) Volcano plot analysis of differentially expressed genes (DEGs) in 3D vs. 2D hAMSCs $(p<0.05$ and fold change $>1.5)$. (c) Expression clusters (z-scores) of both up- and downregulated genes after volcano plot analysis in 2D and 3D hAMSCs. (d) Principal component analysis (PCA) of both 2D and 3D hAMSCs.

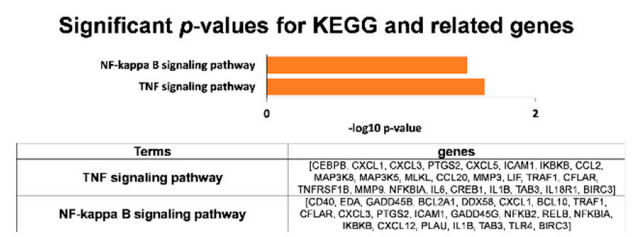

(a)

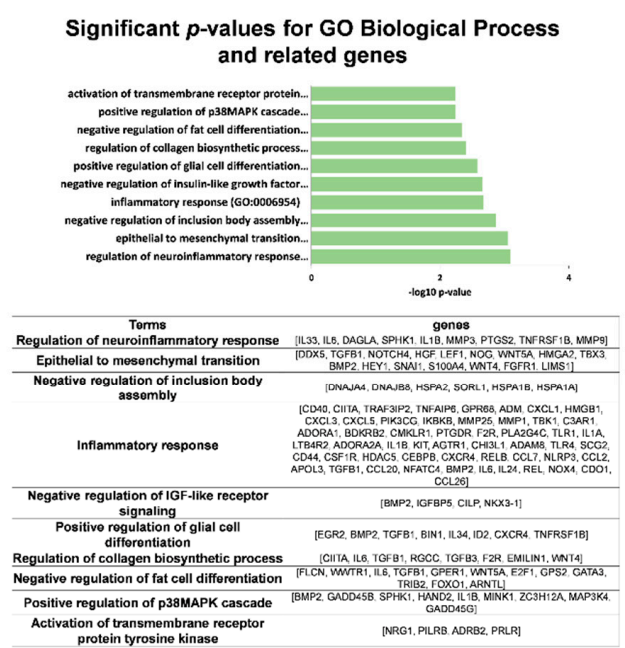

(b)

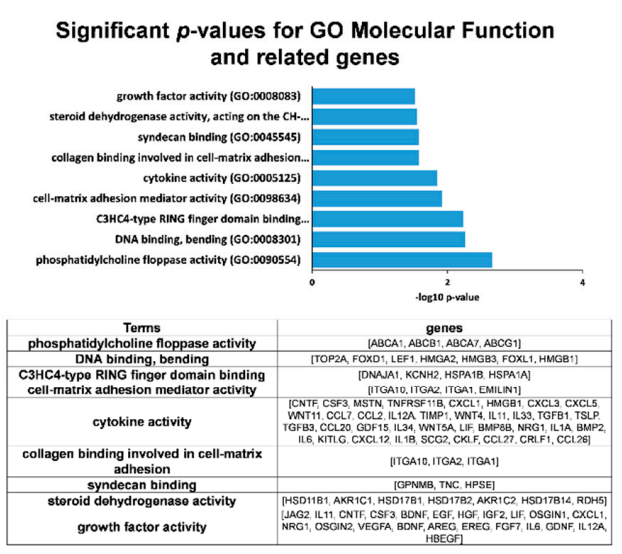

(c)

Figure 3. Functional enrichment analysis on KEGG pathways and Gene Ontology (GO) terms from the top 3000 upregulated genes in 3D vs. 2D hAMSCs. (a) Significant KEGG functional pathways $(p<0.05)$. (b) Significant GO terms of associated biological processes $(p<0.05)$. (c) Significant GO terms of associated molecular function $(p<0.05)$. 
After pathway enrichment analysis, we used qRT-PCR to validate RNA-seq results, detecting 30 randomly selected DEGs. In particular, as shown in Figure $4 \mathrm{a}-\mathrm{c}$, 30 genes we found upregulated by RNA-seq in 3D hAMSCs were significantly correlated with qRT-PCR results, indicating the reliability and accuracy of RNA-seq expression/analysis. The STRING database was used to construct a protein-protein interaction (PPI) map of the 30 aforementioned genes. After, using Cytoscape software, we identified a network with three protein clusters belonging to immune modulation, proliferation/differentiation, and angiogenesis pathways (Figure $4 \mathrm{~d}$ ).

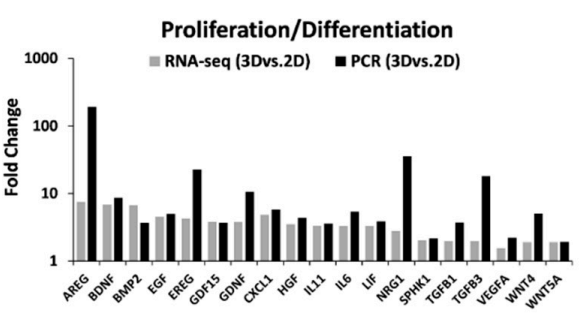

(a)

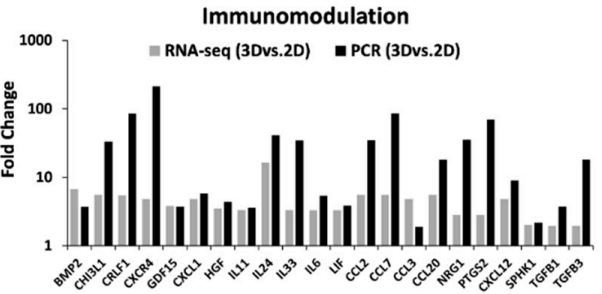

(b)

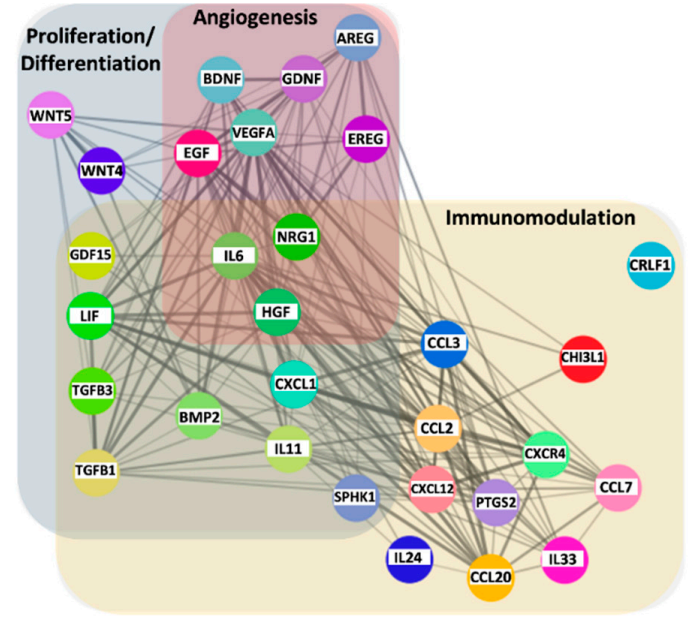

(d)

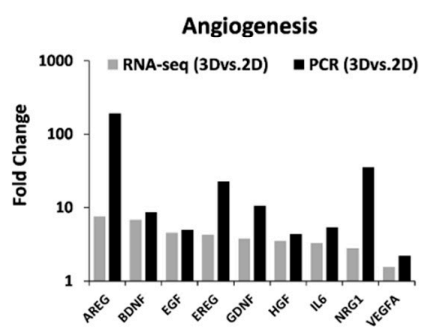

(c)

Figure 4. Transcriptomic analysis revealed 3D-induced hAMSC bioactivity. Upregulated genes involved in (a) proliferation/differentiation, (b) immunomodulatory, and (c) angiogenesis pathways were validated using qRT-PCR, indicating a similar trend. (d) Protein-protein interaction (PPI) network relied on experimentally derived functional and/or structural evidence, including the upregulated genes found.

\subsection{Spheroid Formation of hAMSCs Induced Changes in Methylation Status and Increased the Production of Bioactive Factors}

Using bisulfite sequencing analysis, we examined the methylation status of the 30 upregulated genes found in 3D hAMSCs by both RNA-seq and qRT-PCR (Table 1).

We observed a clear decrease in the methylation levels (all sites) of sixteen genes in 3D hAMSCs compared to 2D hAMSCs (Table 1, bold). Thus, we analyzed the protein expression of the above-described cytokines/chemokines and growth factors in medium conditioned by both 2D and 3D cultures. We detected variable levels of those proteins. In particular, as shown in Figure 5, compared with hAMSCs 2D cultures, 3D spheroids showed significantly enhanced secretory activity for C-X-C motif chemokine ligand 12 (CXCL12), leukemia inhibitory factor (LIF), vascular endothelial growth factor A (VEGF-A), hepatocyte growth factor (HGF), brain-derived neurotrophic factor (BDNF), interleukin-6 (IL6), epidermal growth factor (EGF), prostaglandin E2 (PGE2), chemokine (C-C motif) ligand 20 (CCL20), bone morphogenetic protein 2 (BMP2), transforming growth factor 
beta 1 (TGFB1), C-X-C motif chemokine ligand 1 (CXCL1), C-C motif chemokine ligand 2 (CCL2), growth differentiation factor 15 (GDF15), interleukin-11 (IL11), and chemokine (C-C motif) ligand 7 (CCL7) (9.5-, 8.4-, 7-, 6.9-, 6.6-, 5.7-, 4.7-, 4.2-, 4-, 4-, 3.9-, 3.5-, 3.5-, 3-, 1.8-, and 1.8-fold, respectively).

Table 1. Methylation levels (all sites) of upregulated genes in 2D and 3D hAMSCs.

\begin{tabular}{|c|c|c|c|c|c|c|}
\hline Gene & Chromosome & Start & End & Description & 2D hAMSCs (\%) & 3D hAMSCs (\%) \\
\hline AREG & 4 & 75480629 & 75490486 & Amphiregulin & 74.70 & 73.60 \\
\hline$B D N F$ & 11 & 27676440 & 27743605 & Brain-derived neurotrophic factor & 14.08 & 10.24 \\
\hline$B M P 2$ & 20 & 6748311 & 6760910 & Bone morphogenetic protein 2 & 7.32 & 4.45 \\
\hline CCL2 & 17 & 32582313 & 32584222 & Chemokine (C-C motif) ligand 2 & 24.41 & 12.93 \\
\hline CCL20 & 2 & 228678558 & 228682272 & Chemokine (C-C motif) ligand 20 & 84.90 & 77.06 \\
\hline CCL3 & 17 & 34415602 & 34417515 & Chemokine (C-C motif) ligand 3 & 42.86 & 56.67 \\
\hline CCL7 & 17 & 32597240 & 32599261 & Chemokine (C-C motif) ligand 7 & 45.19 & 39.34 \\
\hline CHI3L1 & 1 & 203148059 & 203155877 & Chitinase 3 -like 1 & 68.58 & 76.02 \\
\hline CRLF1 & 19 & 18704037 & 18717660 & Cytokine receptor-like factor 1 & 17.79 & 17.66 \\
\hline CXCL1 & 4 & 74735110 & 74736959 & Chemokine (C-X-C motif) ligand 1 & 18.06 & 11.30 \\
\hline CXCL12 & 10 & 44793038 & 44881941 & Chemokine (C-X-C motif) ligand 12 & 30.98 & 26.83 \\
\hline CXCR4 & 2 & 136871919 & 136875735 & Chemokine (C-X-C motif) receptor 4 & 7.47 & 6.95 \\
\hline$E G F$ & 4 & 110834040 & 110933422 & Epidermal growth factor & 60.13 & 56.20 \\
\hline EREG & 4 & 75230860 & 75254468 & Epiregulin & 26.62 & 26.19 \\
\hline GDF15 & 19 & 18496968 & 18499986 & Growth differentiation factor 15 & 20.99 & 16.99 \\
\hline GDNF & 5 & 37812779 & 37839788 & Glial cell-derived neurotrophic factor & 16.70 & 16.05 \\
\hline HGF & 7 & 81328322 & 81399754 & Hepatocyte growth factor & 50.33 & 41.92 \\
\hline IL11 & 19 & 55875757 & 55881814 & Interleukin 11 & 26.80 & 21.64 \\
\hline IL24 & 1 & 207070788 & 207077484 & Interleukin 24 & 71.90 & 70.12 \\
\hline IL33 & 9 & 6215805 & 6257983 & Interleukin 33 & 60.55 & 68.69 \\
\hline IL6 & 7 & 22765503 & 22771621 & Interleukin 6 & 19.70 & 12.45 \\
\hline LIF & 22 & 30636436 & 30642840 & Leukemia inhibitory factor & 48.59 & 41.73 \\
\hline NRG1 & 8 & 31496902 & 32622548 & Neuregulin 1 & 37.85 & 36.44 \\
\hline PTGS2 & 1 & 186640923 & 186649559 & $\begin{array}{c}\text { Prostaglandin-endoperoxide } \\
\text { synthase } 2\end{array}$ & 32.49 & 27.00 \\
\hline SPHK1 & 17 & 74372742 & 74383941 & Sphingosine kinase 1 & 14.60 & 13.79 \\
\hline TGFB1 & 19 & 41836813 & 41859831 & Transforming growth factor, beta 1 & 20.05 & 16.55 \\
\hline TGFB3 & 14 & 76424442 & 76449334 & Transforming growth factor, beta 3 & 20.21 & 19.32 \\
\hline$V E G F-A$ & 6 & 43737921 & 43754224 & Vascular endothelial growth factor $A$ & 25.56 & 21.88 \\
\hline WNT4 & 1 & 22446461 & 22470462 & $\begin{array}{l}\text { Wingless-type MMTV integration site } \\
\text { family, member } 4\end{array}$ & 43.70 & 48.77 \\
\hline WNT5A & 3 & 55499743 & 55523973 & $\begin{array}{l}\text { Wingless-type MMTV integration site } \\
\text { family, member } 5 \mathrm{~A}\end{array}$ & 28.81 & 31.67 \\
\hline
\end{tabular}

Bold indicates a significant decrease in the methylation levels in 3D compared to 2D hAMSCs.

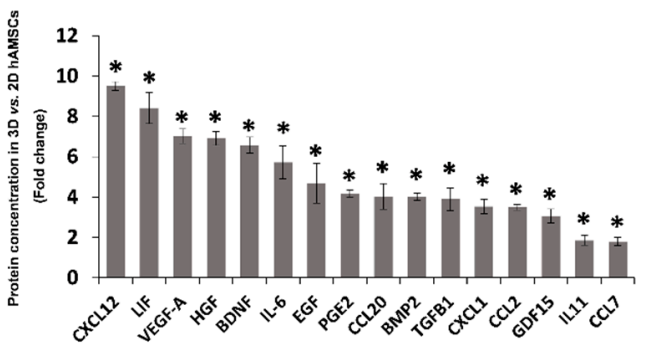

Figure 5. Protein secretion analysis of differentially methylated genes in 2D vs. 3D hAMSCs. * $p<0.05$ vs. 2 D hAMSCs.

\section{Discussion}

Many studies have widely demonstrated that MSCs represent one of the most promising cell products to treat numerous disorders in the field of regenerative medicine [44-46]. Indeed, the therapeutic action of MSCs is being currently investigated in several clinical trials (1356 studies registered at ClinicalTrials.gov) for the treatment of many disorders, including immune, kidney, cardiovascular, neurodegenerative, lung, liver, and orthopedics diseases. On the other hand, MSCs have been shown to have moderate or poor efficacy, and the results from different clinical trials are controversial [15-17]. Moreover, the variability 
and heterogeneity inter-donor or among tissue sources have been proved [47-49]. Overall, those challenges indicate an urgent need to optimize the therapeutic use of MSCs or to enhance MSC capabilities.

In the last decade, in order to promote MSC therapeutic use, different priming strategies have been used according to the injured tissue/organ to be targeted. For instance, the priming of MSCs with proinflammatory cytokines and 3D cultures has been mainly tested to modulate the inflammation and to stimulate angiogenesis in injured tissues $[6,27,39,50]$. Three-dimensional growth of MSCs represents an easy and more physiologic culture that usefully changes MSC phenotype. Many papers have shown the ability of 3D culture to potentiate the therapeutic properties of MSCs, making them more suitable as cell therapeutic products $[3,21,34]$. Santos et al. demonstrated that a $3 \mathrm{D}$ culture model of umbilical cord mesenchymal stromal cells can be used to prime the secretome of those cells for potential clinical applications [38]. Moreover, it has been shown that dynamic 3D techniques for in vitro MSC culture allows the formation of viable compact cellular spheroids with therapeutic properties [20]. Our works also revealed that CM derived from 3D MSCs contained an increased amount of immunosuppressive and growth factors compared to 2D cultures [27], and 3D MSC-CM is capable of attenuating ischemia-reperfusion injury in an in vitro model of the lung [10]. Recently, we have also shown that the paracrine component derived from MSC spheroids was capable of improving in vitro the differentiation of human liver progenitor cells [8]. In that case, our work may suggest that MSCs could also stimulate resident adult stem cells in injured tissue, improving tissue regeneration and function recovery. Therefore, 3D cultures of MSCs can be considered as an advance for the optimization of MSC culture to enhance their therapeutic potential.

To date, the molecular mechanisms contributing to the improvement of MSC spheroid therapeutic properties remain unclear. Several studies have been performed to find gene expression similarity/variability among MSCs derived from different sources [42,51-53]. Moreover, transcriptome analysis was used to study gene expression variations related to specific priming treatments, such as IL-17, IFN- $\gamma$, and hypoxia [40,41]. However, as far as we know, no study has already investigated, by the transcriptome approach, the molecular changes underlying the 3D growth of MSCs. Many scientific data focused on the expression differences within MSCs derived from distinct origins [54-56], but, in the field of MSC therapy, it has become very important also to investigate the differences among MSCs derived from the same tissue. In particular, functional differences could come from different methodological approaches, including chemical or physical treatment of MSCs during culture prior to their use.

To address this, we performed RNA-seq to analyze both 2D and 3D cultures of MSCs derived from the amniotic membrane of the human placenta (hAMSCs) and investigate their molecular variations influencing their therapeutic properties. As shown in Figure 6 (data analysis workflow), to obtain more reliable data, we performed various approaches for the gene screening analysis.

In particular, through RNA-seq analysis, we first revealed that 9221 genes were deregulated, 3899 downregulated, and 5322 upregulated after 3D culture (Figure 2c). Then, we used both KEGG and GO enrichment analyses and identified that several DEGs were related to pathways implicated in regenerative medicine, such as immunomodulation, proliferation/differentiation, and angiogenesis (Figure 3). We used qRT-PCR analysis to validate RNA-seq results and identified 30 DEGs belonging to the above-mentioned pathways (Figure 4). Secondly, on those genes, we further analyzed their methylation status and found significant differences on only 16 genes (Table 1, bold). Finally, we analyzed the protein expression of these genes, and we found that CXCL12, LIF, VEGF-A, HGF, BDNF, IL6, EGF, PGE2, CCL20, BMP2, TGFB1, CXCL1, CCL2, GDF15, IL11, and CCL7 were more secreted by 3D hAMSCs compared to 2D hAMSCs. 


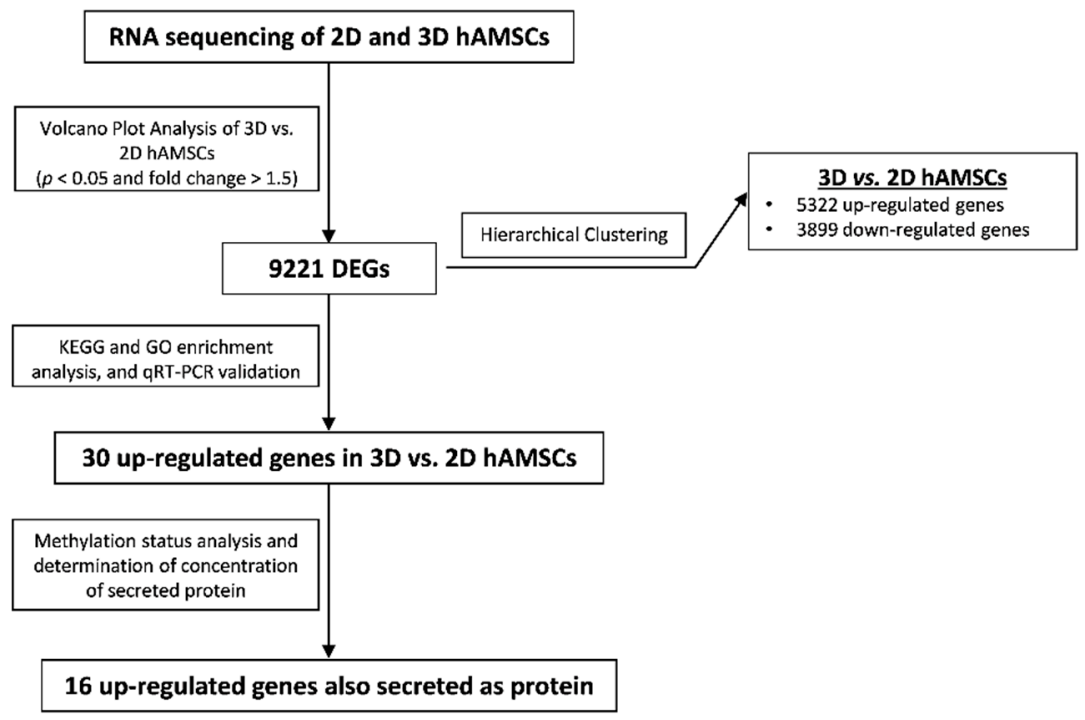

Figure 6. Gene screening process. Data analysis workflow in both 2D and 3D hAMSCs.

Many researchers have previously demonstrated the pleiotropic role of the factors we found upregulated in hAMSC spheroids. It has been shown that BDNF, VEGF-A, IL6, and HGF stimulate angiogenesis both in vitro and in vivo [30,57-60], and EGF, VEGF-A, and HGF were shown to be significantly higher in MSC-treated ischemic tissue, mediating neovascularization effects [61]. The factors described above have also been shown to have immunomodulatory capabilities. Indeed, although we do not yet know the detailed mechanisms by which those factors suppress/modulate immune responses, it has been revealed that MSCs are able to affect immune responses secreting soluble factors, such as TGF 31 , HGF, PGE2, IL6, LIF, and GDF15 [6,27,62,63]. Moreover, it was demonstrated that CCL2, CXCL12, and BMP2 produced by MSCs were able to affect M1 polarization macrophages in favor of the M2 phenotype [64,65], and IL11 was able to induce Th2 polarization of human $\mathrm{CD}^{+} \mathrm{T}$ cells [66]. Interestingly, the above-described factors have also been implicated in tissue regeneration processes. In particular, it was shown that MSCderived CM was enriched in factors, including IL6, HGF, and VEGF-A, and this secretome was able to induce liver regeneration $[5,67]$. Gothelf and collaborators demonstrated that the CM derived from neurotrophic factor-secreting MSCs was enriched with BDNF, VEGF-A, and HGF and has been used effectively to have protective effects in several animal models of neurodegenerative diseases [68]. EGF stimulates the growth of numerous epidermal and epithelial tissues [69], and activation of TGF- $\beta$ is also involved in the recruitment of stem/progenitor cells in tissue regeneration/remodeling processes [70]. Furthermore, it has been proven that LIF, which plays a crucial role in blastocyst implantation, is able to regulate some regenerative processes after injury in several tissues [71]. Oka et al., in an in vivo model, showed that both GDF15 and IL6 cooperate to induce survival of transplanted brown adipose tissues [72]. Finally, high levels of IL6, CCL2, and CXCL1 in the wound microenvironment were associated with tissue repair [73].

To date, by omics techniques, very few works have analyzed the molecular mechanisms underlying MSC priming activation. The characterization of MSC therapeutic properties is problematic due to the variability in the production of different bioactive molecules according to interdonor variation and depending on their origin [49,74]. Moreover, perinatal MSCs, including amniotic-derived MSCs, possess a higher therapeutic potential [49]. Therefore, there is the need to find an easily accessible source of MSCs without invasiveness and to optimize detailed protocols to improve the standardization of MSCs production with effective therapeutic properties.

In our work, we used multiple methodological approaches (RNA-seq, qRT-PCR, methylome analysis, and evaluation of protein secretion) to analyze the gene/protein 
variations among hAMSCs grown as spheroids, which were associated with potential therapeutic properties. We observed that 3D culture conditions generated a large amount of DEGs belonging to the crucial pathways involved in the regenerative processes, such as immunomodulation, proliferation/differentiation, and angiogenesis. Moreover, we revealed that both genetic and epigenetic variations potentially contribute to functional activation of 3D hAMSCs. MSCs derived from the human amniotic membrane of the placenta are a new advantageous source of MSCs, and 3D culture priming of those cells, differently to other priming systems using exogenous factors (IL-17, IFN- $\gamma$, IL1, TNF $\alpha$ ) could represent a useful and natural method to enhance MSC therapeutic properties in a low manipulation setting. This is very crucial in order to implement MSC cellular therapies to be applied in the field of regenerative medicine.

\section{Materials and Methods}

\subsection{Isolation, Culture, and Phenotypic Characterization of Human Amnion-Derived Mesenchymal} Stromal/Stem Cells

MSCs were isolated from the amnion of the human term placenta of healthy donors. Written informed consent and the procedure were approved by ISMETT's Institutional Research Review Board. Informed consent was obtained from each donor. After separation between amnion and chorion, amniotic membrane was cut into small pieces and decontaminated in three different solutions containing: (1) 2.5\% Esojod (Esoform, Rovigo, Italy); (2) $500 \mathrm{U} / \mathrm{mL}$ penicillin, $500 \mathrm{mg} / \mathrm{mL}$ streptomycin, $12.5 \mathrm{mg} / \mathrm{mL}$ amphotericin $\mathrm{B}$, and $1.87 \mathrm{mg} / \mathrm{mL}$ cefamezin (Pfizer, Milan, Italy); (3) $100 \mathrm{U} / \mathrm{mL}$ penicillin and $100 \mathrm{mg} / \mathrm{mL}$ streptomycin. Amniotic fragments were digested for $9 \mathrm{~min}$ at $37^{\circ} \mathrm{C}$ in $\mathrm{HBSS}$ (Lonza, Basel, Switzerland) containing $2.5 \mathrm{U} / \mathrm{mL}$ dispase (Corning, New York, NY, USA) and then maintained for $5 \mathrm{~min}$ in RPMI 1640 (Thermo Fisher Scientific, Waltham, MA, USA). Afterward, the amniotic fragments were further digested with $0.94 \mathrm{mg} / \mathrm{mL}$ collagenase A (Roche, Mannheim, Germany) and $20 \mathrm{mg} / \mathrm{mL}$ DNase (Roche, Mannheim, Germany) for $2.5 \mathrm{~h}$ at $37^{\circ} \mathrm{C}$. The cell suspension obtained was filtered with both $100 \mu \mathrm{m}$ and $70 \mu \mathrm{m}$ cell strainers (BD Falcon, San Jose, CA, USA), pelleted, and resuspended in RPMI for cell counting. Harvested cells were cultured in polystyrene culture dishes (Corning, New York, NY, USA) at $37^{\circ} \mathrm{C}, 5 \% \mathrm{CO}_{2}$, in Chang Medium (Irvine Scientific, Santa Ana, CA, USA). To obtain hAMSCs at different passages, the cells were plated at a density of $1 \times 10^{4} / \mathrm{cm}^{2}$, and after reaching confluence, adherent cells were trypsinized and then subcultured until Passages 3-5. HAMSCs were phenotypically characterized by cytofluorimetric analysis for positive markers (CD90, CD73, and CD13) and negative markers (CD45 and HLA-DR) (BD Biosciences, San Jose, CA, USA). Analysis was performed using the FACSCanto II flow cytometer (Becton Dickinson, Franklin Lakes, NJ, USA) and FACSDiva 8.0.1 (Becton Dickinson, Franklin Lakes, NJ, USA) software.

\subsection{Mesenchymal Stromal/Stem Cell Spheroid Cultures}

HAMSCs at the second passage were cultured as spheroids in a 6-well ultralow attachment plate (Corning, New York, NY, USA), which facilitates spheroid formations and their maintenance. HAMSC spheroids were maintained in DMEM serum-free medium at $5 \% \mathrm{CO}_{2}$ and $37^{\circ} \mathrm{C}$.

\subsection{Conditioned Media Preparation}

To collect CM from 2D culture, after the cells reached 90-95\% confluence, the medium was replaced with serum-free DMEM medium, and the cells were grown for 2 days for CM collection. For 3D cultures, first, we observed the initial spheroid formation for 1 day, after the medium was changed, conditioned for 2 days, and finally collected. The supernatant from each culture was centrifuged and frozen at $-80^{\circ} \mathrm{C}$ until use. 


\subsection{Gene Expression Profiling}

HAMSC total RNA was extracted with the RNeasy Mini Kit and treated with DNase according to the manufacturer's instructions (QIAGEN, Hilden, Germany). Then, it was converted to complementary DNA using the high-capacity cDNA kit (Thermo Fisher Scientific, Waltham, MA, USA). Gene expression was analyzed with the QuantStudio ${ }^{\text {TM }} 7$ Pro RealTime PCR System (Thermo Fisher Scientific, Waltham, MA, USA) using 18S ribosomal RNA (Hs03928985_g1) as housekeeping. We used TaqMan assays for AREG (Hs00950669_m1), BDNF (Hs02718934_s1), BMP2 (Hs00154192_m1), CCL2 (Hs00234140_m1), CCL20 (Hs00355476_m1), CCL3 (Hs00234142_m1), CCL7 (Hs00171147_m1), CHI3L1 (Hs01072228_m1), CRLF1 (Hs00191064_m1), CXCL1 (Hs00236937_m1), CXCL12 (Hs03676656_mH), CXCR4 (Hs00607978_s1), EGF (Hs01099990_m1), EREG (Hs00914313_m1), GDF15 (Hs00171132_m1), GDNF (Hs01931883_s1), HGF (Hs00300159_m1), IL11 (Hs01055414_m1), IL24 (Hs01114274_m1), IL33 (Hs04931857_m1), IL6 (Hs00174131_m1), LIF (Hs01055668_m1), NRG1 (Hs01101538_m1), PTGS2 (Hs00153133_m1), SPHK1 (Hs00184211_m1), TGFB1 (Hs00998133_m1), TGFB3 (Hs01086000_m1), VEGF-A (Hs00900055_m1), WNT4 (Hs01573505_m1), WNT5A (Hs00998537_m1). Reactions were run in duplicate, and calculation of the relative levels of expression was performed according to the comparative Ct-method.

\subsection{Protein Expression Analysis}

The concentration of cytokine and growth factors (CXCL12, LIF, VEGF-A, HGF, BDNF, IL6, EGF, CCL20, BMP2, TGFB1, CXCL1, CCL2, GDF15, and CCL7) in each CM (hAMSCs grown in both 2D and 3D cultures) were determined using magnetic bead technology from Luminex ${ }^{\mathrm{TM}}$ with the ProcartaPlex Multiplex protein assays (Affymetrix, Santa Clara, CA, USA) according to the manufacturer's instructions. The levels of IL11 and PGE-2 were determined using the Human IL-11 Quantikine ELISA Kit and PGE2 Parameter Assay Kit (R\&D Systems, Minneapolis, MN, USA), respectively. The concentration of each factor was calculated from standard curves.

\subsection{RNA-Seq, Library Construction, Sequencing, and Analysis}

Total RNA from 2D and 3D hAMSCs was isolated with RNeasy Micro Kit according to the manufacturer's instructions (QIAGEN, Hilden, Germany). Concentration and quality of RNA were determined using the Qubit 2.0 Fluorometer (Life Technologies, Carlsbad, CA, USA) and 4200 TapeStation System (Agilent Technologies, Santa Clara, CA, USA). Libraries were generated from $1 \mu \mathrm{g}$ of RNA derived from 2D and 3D hAMSC cultures. Poly-A-enriched strand-specific libraries were generated with the TruSeq mRNA V2 sample preparation kit with Ribo-Zero Gold (Illumina, San Diego, CA, USA). The quality and yield of the prepared libraries were assessed using Qubit 2.0 Fluorometer (Life Technologies, Carlsbad, CA, USA) and 4200 TapeStation System (Agilent Technologies, Santa Clara, CA, USA). Sequencing was performed on a NextSeq ${ }^{\text {TM }} 550$ (Illumina, San Diego, CA, USA) with $2 \times 76$ cycles, following the manufacturer's instructions. Quality control checks of the sequencing raw data were conducted with FastQC (v0.11.9, Babraham Institute). Both low-quality read removal and adapter-trimming were performed with trimmomatic (v0.32) [75]. The remaining reads were mapped to human reference genome hg19 with STAR (v2.7.0) [76], and transcript abundances were measured with RSEM (v1.3.3) [77]. We normalized the gene expression level by transcripts per kilobase million (TPM). To identify differentially expressed genes (DEGs), we set the fold change $\geq 1.5$ or $\leq 0.6666$. DEGs were hierarchically clustered using an average linkage algorithm and a "Euclidean distance" for the distance measure using $\mathrm{R}$ functions (v4.1.2). The same software was used to perform principal component analysis (PCA).

\subsection{Bisulfite Genomic Sequencing Analysis of DNA Methylation}

We used bisulfite genomic sequencing as a method of DNA methylation analysis. Briefly, gDNA from 2D and 3D hAMSCs was isolated with the AllPrep DNA/RNA Micro Kit, according to the manufacturer's instructions (QIAGEN, Hilden, Germany). Con- 
centration and quality of gDNA were determined using the Qubit 2.0 Fluorometer (Life Technologies, Carlsbad, CA, USA) and 4200 TapeStation System (Agilent Technologies, Santa Clara, CA, USA). The SureSelect Target Enrichment System (Agilent Technologies, Santa Clara, CA, USA) was used to identify epigenetic changes in 2D and 3D hAMSC cultures. All samples were sequenced using the same workflow. Briefly, $1 \mu \mathrm{g}$ of gDNA was sheared using the Covaris sonicator (Covaris, Woburn, MA, USA) to yield 170-230 bp DNA fragments. The DNA fragments were end-repaired, $3^{\prime}$-adenylated, and further ligated with methylated primers. Following hybridization to biotinylated, plus-strand DNAcomplementary RNA library "baits" and streptavidin bead enrichment, captured DNA was bisulfite-converted using the EZ DNA Methylation Gold Kit (Zymo Research, Irvine, CA, USA). Subsequently, DNA samples were PCR-amplified using barcoded indexed primers to allow for multiplexing. Quality and yield of the DNA sample libraries were assessed using Qubit 2.0 Fluorometer (Life Technologies, Carlsbad, CA, USA) and 4200 TapeStation System (Agilent Technologies, Santa Clara, CA, USA). The pooled libraries were sequenced with the NextSeq 550 (Illumina, San Diego, CA, USA).

\subsection{Whole-Genome Bisulfite Sequencing Data Mapping and Quality Analysis}

On raw data from both bisulfite sequencing converted and non-bisulfite sequencing converted, we performed quality analysis with FastQC (v0.11.9, Babraham Institute, Babraham, UK), and we trimmed with Trim Galore (v0.6.5, Babraham Institute). After, mapping was carried out with Bismark (v0.22.3, Babraham Institute) to hg19 for the human genome. We used SeqMonk software (v1.48.0, Babraham Institute) to quantify the percentage of $\mathrm{CpG}$ methylation values.

\subsection{Pathway Enrichment Analysis}

To find both KEGG and GO terms enriched in the defined gene sets, we used the Enrichr web tool [78]. For figures, we only reported the significant top 10 ranked terms. After gene validation, for map visualization, pathway enrichment analysis results were analyzed by STRING web tool [79] and then interpreted in Cytoscape 3.9.0 [80].

\subsection{Statistics}

All values were expressed as mean \pm SD. Statistical analysis was performed using GraphPad Prism 6.0 (GraphPad Software, San Diego, CA, USA). The Student's t-test was used to compare data. Differences were considered statistically significant at $p<0.05$.

\section{Conclusions}

In conclusion, our work investigated a transcriptomic portrait of hAMSCs in which a significant change in transcriptomic profile was observed in response to 3D culture. The profiling of genes that we found provided new insights related to 3D molecular changes of a new source of MSCs derived from the human amniotic membrane of the placenta. Conventional 2D culture has been seen as a limitation in the wider use of MSC-based therapies, and the development of 3D culture has become a current technological challenge. Indeed, MSCs cultured in monolayer possess limited reproducibility/scalability. Moving MSC culture from a 2D to a 3D suspension culture system allows culturing these cells in a more physiological microenvironment that can potentiate their therapeutic properties. Modulation of the transcriptome/secretome of MSCs is a crucial step toward achievement of the full therapeutic potential of MSCs. Our data revealed that hAMSCs grown in 3D culture represent a promising prime method to improve hAMSC therapeutic properties and highlight the importance of increasing our understanding of MSC biology under different culture/priming methods to optimize their potential therapeutic use. 
Author Contributions: Conceptualization, V.M. and A.G.; methodology, V.M., A.G., N.C., F.C., M.B., M.P., G.A., G.Z., C.C.(Claudia Carcione), and C.C. (Claudio Centi); formal analysis, V.M., A.G., and N.C.; data curation, V.M., A.G., N.C. and F.C.; writing-original draft preparation, V.M.; writingreview and editing, V.M., A.G., M.B., G.Z., A.B. and P.G.C.; supervision, V.M. and P.G.C.; project administration, V.M. and P.G.C.; funding acquisition, V.M. and P.G.C. All authors have read and agreed to the published version of the manuscript.

Funding: This research was funded by UPMC International, Pittsburgh, USA (Project Number: I00000216), and by the Italian Ministry of Education, University and Research, Rome, Italy (IRMI, Project Number: CTN01_00177_888744).

Institutional Review Board Statement: The study was conducted in accordance with the Declaration of Helsinki, and the protocol was approved by ISMETT's Institutional Research Review Board (Project identification code: IRRB/39/20).

Informed Consent Statement: Informed consent was obtained from all subjects involved in the study.

Data Availability Statement: The datasets used and analyzed are available from the corresponding author on reasonable request.

Acknowledgments: The authors thank allmothers who donated placenta.

Conflicts of Interest: The authors declare no conflict of interest.

\section{Abbreviations}

$\begin{array}{ll}\text { 2D } & \text { Two-dimensional } \\ \text { 3D } & \text { Three-dimensional } \\ \text { CM } & \text { Conditioned medium } \\ \text { DEGs } & \text { Differentially expressed genes } \\ \text { GO } & \text { Gene Ontology } \\ \text { hAMSCs } & \text { Amnion-derived mesenchymal stromal/stem cells } \\ \text { KEGG } & \text { Kyoto Encyclopedia of Genes and Genomes } \\ \text { MSCs } & \text { Mesenchymal stromal/stem cells } \\ \text { NGS } & \text { Next-generation sequencing } \\ \text { PCA } & \text { Principal component analysis } \\ \text { PPI } & \text { Protein-protein interactions } \\ \text { RNA-seq } & \text { RNA sequencing } \\ \text { TPM } & \text { Transcripts per kilobase million }\end{array}$

\section{References}

1. Wosczyna, M.N.; Konishi, C.T.; Perez Carbajal, E.E.; Wang, T.T.; Walsh, R.A.; Gan, Q.; Wagner, M.W.; Rando, T.A. Mesenchymal Stromal Cells Are Required for Regeneration and Homeostatic Maintenance of Skeletal Muscle. Cell Rep. 2019, 27, 2029-2035.e5. [CrossRef] [PubMed]

2. Sagaradze, G.; Basalova, N.; Kirpatovsky, V.; Ohobotov, D.; Nimiritsky, P.; Grigorieva, O.; Popov, V.; Kamalov, A.; Tkachuk, V.; Efimenko, A. A magic kick for regeneration: Role of mesenchymal stromal cell secretome in spermatogonial stem cell niche recovery. Stem Cell Res. Ther. 2019, 10, 342. [CrossRef]

3. Miceli, V.; Bulati, M.; Iannolo, G.; Zito, G.; Gallo, A.; Conaldi, P.G. Therapeutic Properties of Mesenchymal Stromal/Stem Cells: The Need of Cell Priming for Cell-Free Therapies in Regenerative Medicine. Int. J. Mol. Sci. 2021, 22, 763. [CrossRef]

4. Lu, Z.; Chen, Y.; Dunstan, C.; Roohani-Esfahani, S.; Zreiqat, H. Priming Adipose Stem Cells with Tumor Necrosis Factor-Alpha Preconditioning Potentiates Their Exosome Efficacy for Bone Regeneration. Tissue Eng. Part A 2017, 23, 1212-1220. [CrossRef] [PubMed]

5. $\quad$ Lee, S.C.; Jeong, H.J.; Lee, S.K.; Kim, S.J. Hypoxic Conditioned Medium from Human Adipose-Derived Stem Cells Promotes Mouse Liver Regeneration through JAK/STAT3 Signaling. Stem Cells Transl. Med. 2016, 5, 816-825. [CrossRef]

6. Bulati, M.; Miceli, V.; Gallo, A.; Amico, G.; Carcione, C.; Pampalone, M.; Conaldi, P.G. The Immunomodulatory Properties of the Human Amnion-Derived Mesenchymal Stromal/Stem Cells Are Induced by INF-gamma Produced by Activated Lymphomonocytes and Are Mediated by Cell-To-Cell Contact and Soluble Factors. Front. Immunol. 2020, 11, 54. [CrossRef]

7. Chinnici, C.M.; Russelli, G.; Bulati, M.; Miceli, V.; Gallo, A.; Busa, R.; Tinnirello, R.; Conaldi, P.G.; Iannolo, G. Mesenchymal stromal cell secretome in liver failure: Perspectives on COVID-19 infection treatment. World J. Gastroenterol. 2021, 27, 1905-1919. [CrossRef] 
8. Lo Nigro, A.; Gallo, A.; Bulati, M.; Vitale, G.; Paini, D.S.; Pampalone, M.; Galvagno, D.; Conaldi, P.G.; Miceli, V. Amnion-Derived Mesenchymal Stromal/Stem Cell Paracrine Signals Potentiate Human Liver Organoid Differentiation: Translational Implications for Liver Regeneration. Front. Med. 2021, 8, 746298. [CrossRef] [PubMed]

9. Maacha, S.; Sidahmed, H.; Jacob, S.; Gentilcore, G.; Calzone, R.; Grivel, J.C.; Cugno, C. Paracrine Mechanisms of Mesenchymal Stromal Cells in Angiogenesis. Stem Cells Int. 2020, 2020, 4356359. [CrossRef]

10. Miceli, V.; Bertani, A.; Chinnici, C.M.; Bulati, M.; Pampalone, M.; Amico, G.; Carcione, C.; Schmelzer, E.; Gerlach, J.C.; Conaldi, P.G. Conditioned Medium from Human Amnion-Derived Mesenchymal Stromal/Stem Cells Attenuating the Effects of Cold IschemiaReperfusion Injury in an in vitro Model Using Human Alveolar Epithelial Cells. Int. J. Mol. Sci. 2021, 22, 510. [CrossRef] [PubMed]

11. Nuzzi, R.; Caselgrandi, P.; Vercelli, A. Effect of Mesenchymal Stem Cell-Derived Exosomes on Retinal Injury: A Review of Current Findings. Stem Cells Int. 2020, 2020, 8883616. [CrossRef]

12. Qian, X.; An, N.; Ren, Y.; Yang, C.; Zhang, X.; Li, L. Immunosuppressive Effects of Mesenchymal Stem Cells-derived Exosomes Stem Cell Rev. Rep. 2021, 17, 411-427. [CrossRef]

13. Sun, H.; Pratt, R.E.; Hodgkinson, C.P.; Dzau, V.J. Sequential paracrine mechanisms are necessary for the therapeutic benefits of stem cell therapy. Am. J. Physiol. Cell Physiol. 2020, 319, C1141-C1150. [CrossRef]

14. Wang, M.; Yan, L.; Li, Q.; Yang, Y.; Turrentine, M.; March, K.; Wang, I.W. Mesenchymal stem cell secretions improve donor heart function following ex vivo cold storage. J. Thorac. Cardiovasc. Surg. 2020. [CrossRef] [PubMed]

15. Fricova, D.; Korchak, J.A.; Zubair, A.C. Challenges and translational considerations of mesenchymal stem/stromal cell therapy for Parkinson's disease. NPJ Regen. Med. 2020, 5, 20. [CrossRef]

16. Lukomska, B.; Stanaszek, L.; Zuba-Surma, E.; Legosz, P.; Sarzynska, S.; Drela, K. Challenges and Controversies in Human Mesenchymal Stem Cell Therapy. Stem Cells Int. 2019, 2019, 9628536. [CrossRef] [PubMed]

17. Squillaro, T.; Peluso, G.; Galderisi, U. Clinical Trials with Mesenchymal Stem Cells: An Update. Cell Transplant. 2016, 25, 829-848. [CrossRef]

18. Tyndall, A. Successes and failures of stem cell transplantation in autoimmune diseases. Hematol. 2010 Am. Soc. Hematol. Educ. Program Book 2011, 2011, 280-284. [CrossRef] [PubMed]

19. Schmelzer, E.; Miceli, V.; Chinnici, C.M.; Bertani, A.; Gerlach, J.C. Effects of Mesenchymal Stem Cell Coculture on Human Lung Small Airway Epithelial Cells. BioMed Res. Int. 2020, 2020, 9847579. [CrossRef] [PubMed]

20. Frith, J.E.; Thomson, B.; Genever, P.G. Dynamic three-dimensional culture methods enhance mesenchymal stem cell properties and increase therapeutic potential. Tissue Eng. Part C Methods 2010, 16, 735-749. [CrossRef]

21. Kouroupis, D.; Correa, D. Increased Mesenchymal Stem Cell Functionalization in Three-Dimensional Manufacturing Settings for Enhanced Therapeutic Applications. Front. Bioeng. Biotechnol. 2021, 9, 621748. [CrossRef] [PubMed]

22. Walter, S.G.; Randau, T.M.; Hilgers, C.; Haddouti, E.M.; Masson, W.; Gravius, S.; Burger, C.; Wirtz, D.C.; Schildberg, F.A. Molecular and Functional Phenotypes of Human Bone Marrow-Derived Mesenchymal Stromal Cells Depend on Harvesting Techniques. Int. J. Mol. Sci. 2020, 21, 4382. [CrossRef] [PubMed]

23. Burja, B.; Barlic, A.; Erman, A.; Mrak-Poljsak, K.; Tomsic, M.; Sodin-Semrl, S.; Lakota, K. Human mesenchymal stromal cells from different tissues exhibit unique responses to different inflammatory stimuli. Curr. Res. Transl. Med. 2020, 68, 217-224. [CrossRef] [PubMed]

24. Tesarova, L.; Jaresova, K.; Simara, P.; Koutna, I. Umbilical Cord-Derived Mesenchymal Stem Cells Are Able to Use bFGF Treatment and Represent a Superb Tool for Immunosuppressive Clinical Applications. Int. J. Mol. Sci. 2020, 21, 5366. [CrossRef]

25. Parolini, O.; Alviano, F.; Bagnara, G.P.; Bilic, G.; Buhring, H.J.; Evangelista, M.; Hennerbichler, S.; Liu, B.; Magatti, M.; Mao, N.; et al. Concise review: Isolation and characterization of cells from human term placenta: Outcome of the first international Workshop on Placenta Derived Stem Cells. Stem Cells 2008, 26, 300-311. [CrossRef]

26. Magatti, M.; Masserdotti, A.; Bonassi Signoroni, P.; Vertua, E.; Stefani, F.R.; Silini, A.R.; Parolini, O. B Lymphocytes as Targets of the Immunomodulatory Properties of Human Amniotic Mesenchymal Stromal Cells. Front. Immunol. 2020, 11, 1156. [CrossRef]

27. Miceli, V.; Pampalone, M.; Vella, S.; Carreca, A.P.; Amico, G.; Conaldi, P.G. Comparison of Immunosuppressive and Angiogenic Properties of Human Amnion-Derived Mesenchymal Stem Cells between 2D and 3D Culture Systems. Stem Cells Int. 2019, 2019, 7486279. [CrossRef]

28. Poggi, A.; Zocchi, M.R. Immunomodulatory Properties of Mesenchymal Stromal Cells: Still Unresolved "Yin and Yang". Curr. Stem Cell Res. Ther. 2019, 14, 344-350. [CrossRef]

29. Fan, X.L.; Zhang, Y.; Li, X.; Fu, Q.L. Mechanisms underlying the protective effects of mesenchymal stem cell-based therapy. Cell. Mol. Life Sci. 2020, 77, 2771-2794. [CrossRef]

30. Tao, H.; Han, Z.; Han, Z.C.; Li, Z. Proangiogenic Features of Mesenchymal Stem Cells and Their Therapeutic Applications. Stem Cells Int. 2016, 2016, 1314709. [CrossRef]

31. Stavely, R.; Nurgali, K. The emerging antioxidant paradigm of mesenchymal stem cell therapy. Stem Cells Transl. Med. 2020, 9 , 985-1006. [CrossRef]

32. Arrigoni, C.; D’Arrigo, D.; Rossella, V.; Candrian, C.; Albertini, V.; Moretti, M. Umbilical Cord MSCs and Their Secretome in the Therapy of Arthritic Diseases: A Research and Industrial Perspective. Cells 2020, 9, 1343. [CrossRef] [PubMed] 
33. Silini, A.R.; Papait, A.; Cargnoni, A.; Vertua, E.; Romele, P.; Bonassi Signoroni, P.; Magatti, M.; De Munari, S.; Masserdotti, A.; Pasotti, A.; et al. CM from intact hAM: An easily obtained product with relevant implications for translation in regenerative medicine. Stem Cell Res. Ther. 2021, 12, 540. [CrossRef]

34. Cesarz, Z.; Tamama, K. Spheroid Culture of Mesenchymal Stem Cells. Stem Cells Int. 2016, 2016, 9176357. [CrossRef] [PubMed]

35. Chen, L.C.; Wang, H.W.; Huang, C.C. Modulation of Inherent Niches in 3D Multicellular MSC Spheroids Reconfigures Metabolism and Enhances Therapeutic Potential. Cells 2021, 10, 2747. [CrossRef] [PubMed]

36. Jaukovic, A.; Abadjieva, D.; Trivanovic, D.; Stoyanova, E.; Kostadinova, M.; Pashova, S.; Kestendjieva, S.; Kukolj, T.; Jeseta, M.; Kistanova, E.; et al. Specificity of 3D MSC Spheroids Microenvironment: Impact on MSC Behavior and Properties. Stem Cell Rev. Rep. 2020, 16, 853-875. [CrossRef]

37. Miceli, V.; Chinnici, C.M.; Bulati, M.; Pampalone, M.; Amico, G.; Schmelzer, E.; Gerlach, J.C.; Conaldi, P.G. Comparative study of the production of soluble factors in human placenta-derived mesenchymal stromal/stem cells grown in adherent conditions or as aggregates in a catheter-like device. Biochem. Biophys. Res. Commun. 2020, 522, 171-176. [CrossRef]

38. Santos, J.M.; Camoes, S.P.; Filipe, E.; Cipriano, M.; Barcia, R.N.; Filipe, M.; Teixeira, M.; Simoes, S.; Gaspar, M.; Mosqueira, D.; et al. Three-dimensional spheroid cell culture of umbilical cord tissue-derived mesenchymal stromal cells leads to enhanced paracrine induction of wound healing. Stem Cell Res. Ther. 2015, 6, 90. [CrossRef]

39. Zimmermann, J.A.; Hettiaratchi, M.H.; McDevitt, T.C. Enhanced Immunosuppression of T Cells by Sustained Presentation of Bioactive Interferon-gamma within Three-Dimensional Mesenchymal Stem Cell Constructs. Stem Cells Transl. Med. 2017, 6, 223-237. [CrossRef] [PubMed]

40. Sivanathan, K.N.; Rojas-Canales, D.; Grey, S.T.; Gronthos, S.; Coates, P.T. Transcriptome Profiling of IL-17A Preactivated Mesenchymal Stem Cells: A Comparative Study to Unmodified and IFN-gamma Modified Mesenchymal Stem Cells. Stem Cells Int. 2017, 2017, 1025820. [CrossRef] [PubMed]

41. Zielniok, K.; Burdzinska, A.; Murcia Pienkowski, V.; Koppolu, A.; Rydzanicz, M.; Zagozdzon, R.; Paczek, L. Gene Expression Profile of Human Mesenchymal Stromal Cells Exposed to Hypoxic and Pseudohypoxic Preconditioning-An Analysis by RNA Sequencing. Int. J. Mol. Sci. 2021, 22, 8160. [CrossRef]

42. Roson-Burgo, B.; Sanchez-Guijo, F.; Del Canizo, C.; De Las Rivas, J. Transcriptomic portrait of human Mesenchymal Stromal/Stem Cells isolated from bone marrow and placenta. BMC Genom. 2014, 15, 910. [CrossRef]

43. Ulloa-Montoya, F.; Kidder, B.L.; Pauwelyn, K.A.; Chase, L.G.; Luttun, A.; Crabbe, A.; Geraerts, M.; Sharov, A.A.; Piao, Y.; Ko, M.S.; et al. Comparative transcriptome analysis of embryonic and adult stem cells with extended and limited differentiation capacity. Genome Biol. 2007, 8, R163. [CrossRef]

44. Han, Y.; Li, X.; Zhang, Y.; Han, Y.; Chang, F.; Ding, J. Mesenchymal Stem Cells for Regenerative Medicine. Cells 2019, 8, 886. [CrossRef] [PubMed]

45. Pittenger, M.F.; Discher, D.E.; Peault, B.M.; Phinney, D.G.; Hare, J.M.; Caplan, A.I. Mesenchymal stem cell perspective: Cell biology to clinical progress. NPJ Regen. Med. 2019, 4, 22. [CrossRef] [PubMed]

46. Vizoso, F.J.; Eiro, N.; Cid, S.; Schneider, J.; Perez-Fernandez, R. Mesenchymal Stem Cell Secretome: Toward Cell-Free Therapeutic Strategies in Regenerative Medicine. Int. J. Mol. Sci. 2017, 18, 1852. [CrossRef] [PubMed]

47. McLeod, C.M.; Mauck, R.L. On the origin and impact of mesenchymal stem cell heterogeneity: New insights and emerging tools for single cell analysis. Eur. Cells Mater. 2017, 34, 217-231. [CrossRef]

48. Sun, C.; Wang, L.; Wang, H.; Huang, T.; Yao, W.; Li, J.; Zhang, X. Single-cell RNA-seq highlights heterogeneity in human primary Wharton's jelly mesenchymal stem/stromal cells cultured in vitro. Stem Cell Res. Ther. 2020, 11, 149. [CrossRef]

49. Wegmeyer, H.; Broske, A.M.; Leddin, M.; Kuentzer, K.; Nisslbeck, A.K.; Hupfeld, J.; Wiechmann, K.; Kuhlen, J.; von Schwerin, C.; Stein, C.; et al. Mesenchymal stromal cell characteristics vary depending on their origin. Stem Cells Dev. 2013, 22, 2606-2618. [CrossRef]

50. Redondo-Castro, E.; Cunningham, C.; Miller, J.; Martuscelli, L.; Aoulad-Ali, S.; Rothwell, N.J.; Kielty, C.M.; Allan, S.M.; Pinteaux, E. Interleukin-1 primes human mesenchymal stem cells towards an anti-inflammatory and pro-trophic phenotype in vitro. Stem Cell Res. Ther. 2017, 8, 79. [CrossRef]

51. Cho, K.A.; Park, M.; Kim, Y.H.; Woo, S.Y.; Ryu, K.H. RNA sequencing reveals a transcriptomic portrait of human mesenchymal stem cells from bone marrow, adipose tissue, and palatine tonsils. Sci. Rep. 2017, 7, 17114. [CrossRef]

52. Jansen, B.J.; Gilissen, C.; Roelofs, H.; Schaap-Oziemlak, A.; Veltman, J.A.; Raymakers, R.A.; Jansen, J.H.; Kogler, G.; Figdor, C.G.; Torensma, R.; et al. Functional differences between mesenchymal stem cell populations are reflected by their transcriptome. Stem Cells Dev. 2010, 19, 481-490. [CrossRef]

53. Sun, C.; Zhang, K.; Yue, J.; Meng, S.; Zhang, X. Deconstructing transcriptional variations and their effects on immunomodulatory function among human mesenchymal stromal cells. Stem Cell Res. Ther. 2021, 12, 53. [CrossRef]

54. Kwon, A.; Kim, Y.; Kim, M.; Kim, J.; Choi, H.; Jekarl, D.W.; Lee, S.; Kim, J.M.; Shin, J.C.; Park, I.Y. Tissue-specific Differentiation Potency of Mesenchymal Stromal Cells from Perinatal Tissues. Sci. Rep. 2016, 6, 23544. [CrossRef]

55. Reinisch, A.; Etchart, N.; Thomas, D.; Hofmann, N.A.; Fruehwirth, M.; Sinha, S.; Chan, C.K.; Senarath-Yapa, K.; Seo, E.Y.; Wearda, T.; et al. Epigenetic and in vivo comparison of diverse MSC sources reveals an endochondral signature for human hematopoietic niche formation. Blood 2015, 125, 249-260. [CrossRef]

56. Sacchetti, B.; Funari, A.; Remoli, C.; Giannicola, G.; Kogler, G.; Liedtke, S.; Cossu, G.; Serafini, M.; Sampaolesi, M.; Tagliafico, E.; et al. No Identical "Mesenchymal Stem Cells" at Different Times and Sites: Human Committed Progenitors of 
Distinct Origin and Differentiation Potential Are Incorporated as Adventitial Cells in Microvessels. Stem Cell Rep. 2016, 6, 897-913. [CrossRef]

57. Greenberg, D.A. Cerebral angiogenesis: A realistic therapy for ischemic disease? Methods Mol. Biol. 2014, 1135, $21-24$.

58. Kwon, H.M.; Hur, S.M.; Park, K.Y.; Kim, C.K.; Kim, Y.M.; Kim, H.S.; Shin, H.C.; Won, M.H.; Ha, K.S.; Kwon, Y.G.; et al. Multiple paracrine factors secreted by mesenchymal stem cells contribute to angiogenesis. Vasc. Pharmacol. 2014, 63, 19-28. [CrossRef] [PubMed]

59. Sun, Y.; Jin, K.; Xie, L.; Childs, J.; Mao, X.O.; Logvinova, A.; Greenberg, D.A. VEGF-induced neuroprotection, neurogenesis, and angiogenesis after focal cerebral ischemia. J. Clin. Investig. 2003, 111, 1843-1851. [CrossRef] [PubMed]

60. Usui, T.; Naruo, A.; Okada, M.; Hayabe, Y.; Yamawaki, H. Brain-derived neurotrophic factor promotes angiogenic tube formation through generation of oxidative stress in human vascular endothelial cells. Acta Physiol. 2014, 211, 385-394. [CrossRef] [PubMed]

61. Han, Y.S.; Lee, J.H.; Yoon, Y.M.; Yun, C.W.; Noh, H.; Lee, S.H. Hypoxia-induced expression of cellular prion protein improves the therapeutic potential of mesenchymal stem cells. Cell Death Dis. 2016, 7, e2395. [CrossRef] [PubMed]

62. Liu, J.; Kumar, S.; Heinzel, A.; Gao, M.; Guo, J.; Alvarado, G.F.; Reindl-Schwaighofer, R.; Krautzberger, A.M.; Cippa, P.E.; McMahon, J.; et al. Renoprotective and Immunomodulatory Effects of GDF15 following AKI Invoked by Ischemia-Reperfusion Injury. J. Am. Soc. Nephrol. 2020, 31, 701-715. [CrossRef]

63. Najar, M.; Raicevic, G.; Fayyad-Kazan, H.; Bron, D.; Toungouz, M.; Lagneaux, L. Mesenchymal stromal cells and immunomodulation: A gathering of regulatory immune cells. Cytotherapy 2016, 18, 160-171. [CrossRef] [PubMed]

64. Giri, J.; Das, R.; Nylen, E.; Chinnadurai, R.; Galipeau, J. CCL2 and CXCL12 Derived from Mesenchymal Stromal Cells Cooperatively Polarize IL-10+ Tissue Macrophages to Mitigate Gut Injury. Cell Rep. 2020, 30, 1923-1934.e4. [CrossRef] [PubMed]

65. Wei, F.; Zhou, Y.; Wang, J.; Liu, C.; Xiao, Y. The Immunomodulatory Role of BMP-2 on Macrophages to Accelerate Osteogenesis. Tissue Eng. Part A 2018, 24, 584-594. [CrossRef]

66. Curti, A.; Ratta, M.; Corinti, S.; Girolomoni, G.; Ricci, F.; Tazzari, P.; Siena, M.; Grande, A.; Fogli, M.; Tura, S.; et al. Interleukin-11 induces Th2 polarization of human CD4 (+) T cells. Blood 2001, 97, 2758-2763. [CrossRef]

67. Yu, J.; Yin, S.; Zhang, W.; Gao, F.; Liu, Y.; Chen, Z.; Zhang, M.; He, J.; Zheng, S. Hypoxia preconditioned bone marrow mesenchymal stem cells promote liver regeneration in a rat massive hepatectomy model. Stem Cell Res. Ther. 2013, 4, 83. [CrossRef]

68. Gothelf, Y.; Abramov, N.; Harel, A.; Offen, D. Safety of repeated transplantations of neurotrophic factors-secreting human mesenchymal stromal stem cells. Clin. Transl. Med. 2014, 3, 21. [CrossRef]

69. Bavaro, T.; Tengattini, S.; Rezwan, R.; Chiesa, E.; Temporini, C.; Dorati, R.; Massolini, G.; Conti, B.; Ubiali, D.; Terreni, M. Design of epidermal growth factor immobilization on 3D biocompatible scaffolds to promote tissue repair and regeneration. Sci. Rep. 2021, 11, 2629. [CrossRef]

70. Xu, X.; Zheng, L.; Yuan, Q.; Zhen, G.; Crane, J.L.; Zhou, X.; Cao, X. Transforming growth factor-beta in stem cells and tissue homeostasis. Bone Res. 2018, 6, 2. [CrossRef]

71. Xue, B.; Liu, D.; Song, M.; Zhao, G.; Cao, Y.; Yan, G.; Dai, J.; Hu, Y. Leukemia inhibitory factor promotes the regeneration of rat uterine horns with full-thickness injury. Wound Repair Regen. 2019, 27, 477-487. [CrossRef]

72. Oka, M.; Kobayashi, N.; Matsumura, K.; Nishio, M.; Nakano, K.; Okamura, T.; Okochi, H.; Minamisawa, T.; Shiba, K.; Saeki, K New Role for Growth/Differentiation Factor 15 in the Survival of Transplanted Brown Adipose Tissues in Cooperation with Interleukin-6. Cells 2020, 9, 1365. [CrossRef] [PubMed]

73. Gawriluk, T.R.; Simkin, J.; Hacker, C.K.; Kimani, J.M.; Kiama, S.G.; Ezenwa, V.O.; Seifert, A.W. Complex Tissue Regeneration in Mammals Is Associated with Reduced Inflammatory Cytokines and an Influx of T Cells. Front. Immunol. 2020, 11, 1695. [CrossRef] [PubMed]

74. Gray, A.; Schloss, R.S.; Yarmush, M. Donor variability among anti-inflammatory pre-activated mesenchymal stromal cells. Technology 2016, 4, 201-215. [CrossRef] [PubMed]

75. Bolger, A.M.; Lohse, M.; Usadel, B. Trimmomatic: A flexible trimmer for Illumina sequence data. Bioinformatics 2014, 30, 2114-2120 [CrossRef]

76. Dobin, A.; Davis, C.A.; Schlesinger, F.; Drenkow, J.; Zaleski, C.; Jha, S.; Batut, P.; Chaisson, M.; Gingeras, T.R. STAR: Ultrafast universal RNA-seq aligner. Bioinformatics 2013, 29, 15-21. [CrossRef]

77. Li, B.; Dewey, C.N. RSEM: Accurate transcript quantification from RNA-Seq data with or without a reference genome. BMC Bioinform. 2011, 12, 323. [CrossRef]

78. Kuleshov, M.V.; Jones, M.R.; Rouillard, A.D.; Fernandez, N.F.; Duan, Q.; Wang, Z.; Koplev, S.; Jenkins, S.L.; Jagodnik, K.M.; Lachmann, A.; et al. Enrichr: A comprehensive gene set enrichment analysis web server 2016 update. Nucleic Acids Res. 2016, 44, W90-W97. [CrossRef]

79. Szklarczyk, D.; Gable, A.L.; Lyon, D.; Junge, A.; Wyder, S.; Huerta-Cepas, J.; Simonovic, M.; Doncheva, N.T.; Morris, J.H.; Bork, P.; et al. STRING v11: Protein-protein association networks with increased coverage, supporting functional discovery in genome-wide experimental datasets. Nucleic Acids Res. 2019, 47, D607-D613. [CrossRef]

80. Shannon, P.; Markiel, A.; Ozier, O.; Baliga, N.S.; Wang, J.T.; Ramage, D.; Amin, N.; Schwikowski, B.; Ideker, T. Cytoscape: A software environment for integrated models of biomolecular interaction networks. Genome Res. 2003, 13, 2498-2504. [CrossRef] 